\title{
Risk factors for longer hospital stay in children with hepatitis A infections
}

\section{Hepatit A enfeksiyonu olan çocuklarda hastanede yatış süresinin uzamasında rol oynayan risk faktörleri}

\author{
Ahu KARA ${ }^{1}$, Arzu HALCI UĞUR ${ }^{2}$, Nuri BAYRAM ${ }^{1}$, İlker DEVRİM ${ }^{1}$ \\ ${ }^{1}$ İzmir Dr. Behçet Uz Çocuk Hastanesi, Çocuk Enfeksiyon Hastalıkları, İzmir \\ ${ }^{2}$ İzmir Dr. Behçet Uz Çocuk Hastanesi, Çocuk Sağlı ğı ve Hastalıkları, İzmir
}

\begin{abstract}
Objective: We evaluated the risk factors for longer hospitalization with hepatitis A virus infection.

Methods: Pediatric patients younger than 18 years of age admitted between January 1, 2010 and December 31, 2014 with the serological diagnosis of hepatitis A were evaluated retrospectively.

Results: Of 133 patients, $41.4 \%$ were female and $58.6 \%$ were male. The median age of the patients was 8.0 years (range, 6 months - 15 years). The median hospital stay was 3 days (range, 1- 29 days). There was no statistically significant difference between the children with prolonged and shorter hospital stay regarding the presence of high ALT and AST levels, leukopenia or leukocytosis, fever, prolonged coagulation time, intravenous fluid, and vitamin $K$ administration or poor oral intake $(p>0.05)$. The frequency of thrombocytopenia in children with prolonged hospital stay was significantly higher compared to the children with shorter stay $(p=0.013)$. In terms of atypical course, two patients had fulminant hepatitis, one had cholestatic hepatitis. Conclusion: Thrombocytopenia at the presentation of HAV infections in children may be the predictor for longer hospital stay.
\end{abstract}

Key words: Fulminant hepatitis, hepatitis A, cholestatic hepatitis, thrombocytopenia

$\ddot{\mathbf{o z}}$

Amaç: Hepatit A virüs enfeksiyonu ile hastanede yatışın süresinin uzamasında rol oynayan risk faktörlerinin değerlendirilmesi.

Yöntem: 1 Ocak 2010 ve 31 Aralık 2014 tarihleri arasında hepatit A serolojik tanısı ile başvuran 18 yaşından küçük hastalar retrospektif olarak değerlendirildi.

Bulgular: Yüz otuz üç hastanın, \%41,4'ü kız ve \%58,6'sı erkekti. Hastaların ortanca yaşı (6 ay-15 yaş) 8.0 yaş idi. Ortalama hastanede kalış süresi 3 gün (1-29 gün) idi. Hastanede yatış süreleri ile yüksek ALT ve AST düzeyleri, lökopeni veya lökositoz, ateş varlığı, uzamış pıhtılaşma zamanı, intravenöz sıvı alımı, K vitamini uygulanması ya da oral alımın kötü olması arasında istatistiksel olarak anlamlı bir fark saptanmadı $(p>0,05)$. Trombositopeni oranı hastanede uzun süre kalan çocuklarda daha kısa süre kalan çocuklara göre istatistiksel olarak anlamlı daha yüksek saptandı $(p=0,013)$. İki hastada fulminan hepatit, bir hastada da kolestatik hepatit mevcuttu.

Sonuç: Trombositopeni HAV enfeksiyonu olan çocuklarda hastanede daha uzun süre yatış için bir belirleyici olabilir.

Anahtar kelimeler: Fulminan hepatit, hepatit A, kolestatik hepatit, trombositopeni

Alındığı tarih: 11.11.2016

Kabul tarihi: 16.11 .2016

Yazışma adresi: Uzm. Dr. Ahu Kara, İsmet Kaptan Mah., Sezer Doğan Sok. No:11, Konakİzmir

e-mail: ahukara01@hotmail.com

\section{INTRODUCTION}

Hepatitis A is a vaccine-preventable, self-limiting infection of the liver caused by hepatitis A virus $(\mathrm{HAV})^{(1)}$. The clinical spectrum ranges from mostly asymptomatic infection to a more rarely seen fulmi- 
nant hepatitis ${ }^{(2-5)}$. In symptomatic children, the most common symptoms are fever, loss of appetite, nausea, fatigue and abdominal pain, followed within a few days by jaundice. Transmission is primarily by the fecal-oral route, including person-to-person spread and contaminated food or water ${ }^{(1)}$.

The course and outcome of the disease is mainly depended on the age. Hepatitis A was reported to be symptomatic in only $4 \%-16 \%$ of children compared to $75 \%-95 \%$ of adults. The degree of endemicity differs in different geographical regions. Turkey, was an intermediate endemic country for HAV, and seropositivity had been reported to change according to the geographical area ${ }^{(6)}$. It was reported that seropositivity of HAV had turned to positive in earlier ages in eastern Anatolia compared to western parts of our country such as our city, Izmir ${ }^{(7-9)}$.

In this study, we aimed to determine the possible risk factors for progression and prolonged hospital stay in children with HAV infections in a low endemic region for HAV infections.

\section{MATERIAL and METHODS}

In this study, pediatric patients younger than 18 years of age admitted between January 1, 2010 and December 31, 2014 with the serological diagnosis of hepatitis A were evaluated retrospectively. Exclusion criteria was negative anti-HAV IgM results. Demographic data included age, gender, symptoms (fever and vomiting), results of laboratory studies [hemogram, biochemical studies, prothrombin (PT) and activated thromboplastin time (aPTT)], hospitalization period, complications (if present), duration of fever (if present), times of applied vitamin K, family history for hepatitis A, and outcome of the patient. An atypical course of HAV was categorised as cholestatic hepatitis and fulminant hepatitis. Cholestatic hepatitis was defined based on direct bilirubin level higher than $50 \%$ of total bilirubin level and total bilirubin level higher than $10 \mathrm{mg} / \mathrm{dl}$ over a four-week period. Fulminant hepatitis was defined as worsening of icterus, liver functions and presence of hepatic encephalopathy within a two-week period.

The prolonged hospital stay was defined as hospi- talization longer or equal to 5 days. Thrombocytopenia was defined as thrombocyte count lower than 150.000/ $\mathrm{mm}^{3}$; leukopenia as white blood cell count (WBC) $<4,000 / \mathrm{mm}^{3}$ and leukocytosis as $\mathrm{WBC}>10.400 / \mathrm{mm}^{3}$. Alanine aminotransferase (ALT) and aspartate aminotransferase (AST) levels were divided into three groups as follows <1500; 1500-3000, $>3000 \mathrm{IU} / \mathrm{L}$.

Statistical analysis was performed with the Statistical Package for the Social Sciences version 18.0 (SPSS, Microsoft Inc. Chicago, USA). Continuous variables were described as arithmetical means with standard deviations (SD) or as medians if not normally distributed. Mann-Whitney U test was used to compare medians of two independent groups. Categorical variables were described as absolute frequencies and proportions. A p value of 0.05 was considered statistically significant.

\section{RESULTS}

Among 133 patients hospitalized with the diagnosis of HAV infection, $41.4 \%$ were female and $58.6 \%$ were male. The median age of the patients was 8.0 years (range, 6 months- 15 years). Distribution according to age was summarized in Table 1.

Table 1. Distribution according to age and gender.

\begin{tabular}{|c|c|c|c|c|c|c|}
\hline \multirow[b]{3}{*}{ Age groups (years) } & \multicolumn{4}{|c|}{ Gender } & & \\
\hline & \multicolumn{2}{|c|}{ Female } & \multicolumn{2}{|c|}{ Male } & \multicolumn{2}{|c|}{ Total } \\
\hline & $\mathbf{n}$ & $\%$ & $\mathbf{n}$ & $\%$ & $\mathbf{n}$ & $\%$ \\
\hline 6 months- 5 years & 11 & 45.8 & 13 & 54.2 & 24 & 100 \\
\hline $5-10$ years & 26 & 37.1 & 44 & 62.9 & 70 & 100 \\
\hline$>10$ years & 18 & 46.2 & 21 & 53.8 & 39 & 100 \\
\hline Total & 55 & 41.4 & 78 & 58.6 & 133 & 100 \\
\hline
\end{tabular}

Among the study group, patients with poor oral intake due to vomiting $(\mathrm{n}=120 ; 90.2 \%)$, coagulopathy $(n=54 ; 40.6 \%)$, fever $(n=31 ; 23.3 \%)$, and cholestatic hepatitis $(n=10 ; 7.5 \%)$ were hospitalized in our clinic.

A total of $31(23.3 \%)$ of patients had fever and 120 (90.2\%) patients had vomiting. Only 29 patients (21.8\%) patients had had close contact with an HAVinfected person in the household.

Coagulopathy was observed in 54 (40.6\%) and 
abnormal APTT in 5 cases (3.8\%). Totally $42(31.6 \%)$ patients had vitamin K therapy and 120 patients $(90.2 \%)$ intravenous fluid therapy.

Laboratory studies yielded leukopenia $(<4.000 /$ $\left.\mathrm{mm}^{3}\right)$ in $9.8 \%$, leukocytosis $\left(>10.400 / \mathrm{mm}^{3}\right)$ in $14.3 \%$, and thrombocytopenia $\left(<150.000 / \mathrm{mm}^{3}\right)$ in $8.3 \%$ of the patients. Other laboratory parametres analyzed are shown in Table 2. Among 133 patients; ALT levels were lower than $1500 \mathrm{U} / \mathrm{L}$ in $65(48.9 \%)$, $1500-3000 \mathrm{IU} / \mathrm{L}$ in 45 (3.8\%), and higher than 3000 IU/L in $23(17.3 \%)$ patients, while AST levels were lower than $1500 \mathrm{IU} / \mathrm{L}$ in 75 (56.4\%), 1500-3000 IU/L in $57(37.6 \%)$, and higher than $3000 \mathrm{IU} / \mathrm{L}$ in $8(6 \%)$ patients(Table 3). Among cases with prolonged coagulation time coagulopathy (PT $>14.5 \mathrm{sn}$ ) was observed in $54(40.6 \%)$ and abnormal aPTT (>40.3 sn) in $5(3.8 \%)$. cases Forty-two (31.6\%) patients received treatment for vitamin K. Nine of these received more than one vitamin $\mathrm{K}$ administration (Tablo 3 ).

Table 2. Comparison of the children with prolonged hospital stay ( $\geq 5$ days) versus shorter hospital stay( $<5$ days).

\begin{tabular}{lcc}
\hline & \multicolumn{2}{c}{ Hospitalization period } \\
\cline { 2 - 3 } Laboratory studies & $\mathbf{<}$ days & $\mathbf{\geq 5}$ days \\
\hline & \multicolumn{2}{c}{ Median (min-max.) } \\
AST (IU/L) & 1,479 & 1,104 \\
& $(104-3,993)$ & $(170-5,598)$ \\
ALT (IU/L) & 1,661 & 1,237 \\
& $(136-3,585)$ & $(141-5,673)$ \\
Total bilirubin (mg/dL) & 5.1 & 4.5 \\
& $(0.3-27)$ & $(0.5-24.8)$ \\
Direkt bilirubin (mg/dL) & 3.4 & 3.1 \\
& $(0.1-14.5)$ & $(0-15.9)$ \\
Hemoglobin $(\mathrm{g} / \mathrm{dL})$ & 12.7 & 12.5 \\
& $(9.2-15.9)$ & $(8.9-14.5)$ \\
WBC $\left(/ \mathrm{mm}^{3}\right)$ & 6,100 & 5,800 \\
& $(2,900-17,500)$ & $(1,100-27,500)$ \\
Platelet $\left(/ \mathrm{mm}^{3}\right)$ & 276,000 & 254,000 \\
& $(27,000-665,000)$ & $(12,000-959,000)$ \\
& \multicolumn{2}{c}{} \\
\hline
\end{tabular}

The median hospital stay was 3 days (range, 1-29 days). Among them 95 (71.5\%) patients had been hospitalized at our clinic for a period shorter than 5 days, while 38 (28.5\%) patients for at least 5 days.

The median levels of AST, ALT, total and direct bilirubin, hemoglobin levels, WBC and platelet count were not significantly different between the two groups ( $>0.05)$ (Table 2).
There was no statistically significant difference between the children with prolonged and shorter hospital stay regarding presence of high ALT and AST levels, leukopenia or leukocytosis, fever, prolonged coagulation time, intravenous fluid, and administration of vitamin $\mathrm{K}$ or poor oral intake $(\mathrm{p}>0.05)$. The ratio of thrombocytopenia in children with prolonged hospital stay was significantly higher compared to the children with shorter stay $(\mathrm{p}=0.013)$ (Table 3).

In terms of atypical course two patients $(1.5 \%)$ had fulminant hepatitis and one patient cholestatic hepatitis. These patients were admitted with vomiting, jaundice, and abdominal pain. In addition, patient with cholestatic hepatitis had pale stools and hepatomegaly. In this cholestatic patient, AST and ALT values were more than $3000 \mathrm{IU} / \mathrm{L}$, PT and PTT values were 63 secs and 60 secs, respectively, total bilirubin/direct bilirubin were $27 / 14 \mathrm{mg} / \mathrm{dL}$. In one of patient with fulminant hepatitis, AST and ALT values were 3737 IU/L and 5673 IU/L, respectively. The other patient with fulminant hepatitis, AST and ALT values were $1345 \mathrm{IU} / \mathrm{L}$ and $960 \mathrm{IU} / \mathrm{L}$, respectively Coagulation factors and bilirubin levels were above the normal ranges. Three patients with fulminant hepatitis and cholestatic hepatitis were transferred to another hospital for liver transplantation.

\section{DISCUSSION}

Acute HAV infection is the most common form of acute viral hepatitis throughout the world. Among children, approximately $70 \%$ to $80 \%$ of all new cases of viral hepatitis are caused by HAV. It is mainly transmitted by ingestion of contaminated food or water or through contact with an infected patient ${ }^{(1,2)}$. Although hepatitis A vaccine was included in the national vaccination program; hepatitis A has shown intermediate endemicity in our country.

In our study, the median hospitalization time was shorter compared to previous studies. The hospitalization period was reported as 6.8 days in Spain; 6.7 days in Korea and 5.2 days in Turkey ${ }^{(7,10,11)}$.

Approximately $90 \%$ of the children have been infected by the age of 10 years ${ }^{(3)}$. However in our study; more than one third of the immunized children 
Table 3. Possible risk factors for longer hospital stay ( $\geq 5$ days).

\begin{tabular}{|c|c|c|c|c|}
\hline & \multicolumn{4}{|c|}{ Hospital stay (day) } \\
\hline & $<5$ & $\geq 5$ & Total & $p$ values \\
\hline \multicolumn{5}{|l|}{ Age } \\
\hline 6 months -5 years & $24(18.0 \%)$ & $13(9.8 \%)$ & $37(27.8 \%)$ & $\mathrm{p}>0.05$ \\
\hline 5-10 years & $34(25.6 \%)$ & $14(10.5 \%)$ & $48(36.1 \%)$ & \\
\hline$>10$ years & $37(27.8 \%)$ & $11(8.3 \%)$ & $48(36.1 \%)$ & \\
\hline \multicolumn{5}{|l|}{ Prolonged PT } \\
\hline Normal & $56(42.1 \%)$ & $23(17.3 \%)$ & $79(59.4 \%)$ & $\mathrm{p}>0.05$ \\
\hline Abnormal & $39(29.3 \%)$ & $15(11.3 \%)$ & $54(40.6 \%)$ & \\
\hline \multicolumn{5}{|l|}{ Prolonged PTT } \\
\hline Normal & $93(69.9 \%)$ & $35(26.3 \%)$ & $138(96.2 \%)$ & $\mathrm{p}>0.05$ \\
\hline Abnormal & $2(1.5 \%)$ & $3(2.3 \%)$ & $5(3.8 \%)$ & \\
\hline \multicolumn{5}{|l|}{ WBC count } \\
\hline High & $13(9.8 \%)$ & $6(4.5 \%)$ & $19(14.3 \%)$ & \\
\hline Normal & $76(57.1 \%)$ & $25(18.8 \%)$ & $101(75.9 \%)$ & $\mathrm{p}>0.05$ \\
\hline Low & $6(4.5 \%)$ & $7(5.3 \%)$ & $13(9.8 \%)$ & \\
\hline \multicolumn{5}{|l|}{ Platelet count } \\
\hline Thrombocytopenia & $4(3.0 \%)$ & $7(5.3 \%)$ & $11(8.3 \%)$ & $\mathrm{p}=0.013^{*}$ \\
\hline Normal & $91(68.4 \%)$ & $31(23.3 \%)$ & $122(91.7 \%)$ & \\
\hline \multicolumn{5}{|l|}{ Presence of fever } \\
\hline Yes & $19(14.3 \%)$ & $12(9.0 \%)$ & $31(23.3 \%)$ & $\mathrm{p}>0.05$ \\
\hline No & $76(57.1 \%)$ & $26(19.5 \%)$ & $102(76.7 \%)$ & \\
\hline \multicolumn{5}{|l|}{ Oral fluid intake } \\
\hline Poor & $85(63.9 \%)$ & $35(26.3 \%)$ & $120(90.2 \%)$ & $\mathrm{p}>0.05$ \\
\hline Normal & $10(7.5 \%)$ & $3(2.3 \%)$ & $13(9.8 \%)$ & \\
\hline \multicolumn{5}{|c|}{ Intravenous fluid administration } \\
\hline Yes & $85(63.9 \%)$ & $35(26.3 \%)$ & $120(90.2 \%)$ & $\mathrm{p}>0.05$ \\
\hline No & $10(7.5 \%)$ & $3(2.3 \%)$ & $13(9.8 \%)$ & \\
\hline \multicolumn{5}{|c|}{ Vitamin K administration } \\
\hline Yes & $31(23.3 \%)$ & $11(8.3 \%)$ & $42(31.6 \%)$ & $\mathrm{p}>0.05$ \\
\hline No & 64 & $27(20.3 \%)$ & $91(68.4 \%)$ & \\
\hline \multicolumn{5}{|l|}{ AST levels (IU/L) } \\
\hline$<1500$ & $48(36.1 \%)$ & $27(20.3 \%)$ & $75(56.4 \%)$ & $\mathrm{p}>0.05$ \\
\hline $1500-3000$ & $43(32.3 \%)$ & $7(5.3 \%)$ & $57(37.6 \%)$ & \\
\hline$>3000$ & $4(3.0 \%)$ & $4(3.0 \%)$ & $8(6.0 \%)$ & \\
\hline \multicolumn{5}{|l|}{ ALT levels (IU/L) } \\
\hline$<1500$ & $43(12.8 \%)$ & $22(9.0 \%)$ & $65(48.9 \%)$ & $\mathrm{p}>0.05$ \\
\hline $1500-3000$ & $34(33.8 \%)$ & $11(14.3 \%)$ & $45(33.8 \%)$ & \\
\hline$>3000$ & $18(24.8 \%)$ & $5(5.3 \%)$ & $23(17.3 \%)$ & \\
\hline
\end{tabular}

were older than 10 years due to their being in the low endemic region of Turkey ${ }^{(6)}$. A previous study from India ${ }^{(12)}$, reported that the mean age of 117 children with HAV infection was 7.85 \pm 3.4 years. A recent study from Turkey evaluating 427 pediatric patients, the mean age for contracting HAV infection was reported to be $8.7 \pm 3.5$ years ${ }^{(7)}$. Our findings supported the results of the previous studies however in our study higher proportion of children were older than 10 years.

Previous studies reported that among patients with HAV infection, $45 \%$ were reported to be in close contact with an HAV-infected person, and secondary HAV infection was noted in $54 \%$ of the patients ${ }^{(13)}$. In a study from Turkey, it was reported that $28.5 \%$ of the patients had had close contact with an HAVinfected person ${ }^{(7)}$. Similarly in our study, $21.8 \%$ of the patients had had close contact with an HAVinfected person. These results emphasize the importance of preventive measures when a case with HAV is detected.

Elevation in ALT and AST levels is one of the first signs of hepatocellular inflammation and liver injury. However in our study, higher ALT or AST levels 
were found to have no effect on hospital stay $(p>0.05)$. Since two patients with ALT and AST levels higher than $3000 \mathrm{IU} / \mathrm{L}$ and one patient with hepatic transaminase levels above $1000 \mathrm{IU} / \mathrm{L}$ had underwent liver transplantation; in our opinion hepatic transaminases could not be predictors for longer hospital stay or transplantation.

In one study from Korea; analyzing 3127 adult and children, it was reported that abnormalities in hematological parameters were more severe in the younger group, especially regarding decreased leukocyte count ${ }^{(10)}$. However in our study, hospital stay was not associated with having leukocytosis or leukopenia, which suggested that these parameters were not strictly associated with prognosis.

In our study; thrombocytopenia was present in $8.3 \%$ of the patients with HAV infection which was relatively high compared to the recent studies. Kumar et al. ${ }^{(12)}$ reported the rate of thrombocytopenia as $5.1 \%$ and Çetinkaya et al. ${ }^{(7)}$ as $2.6 \%$. Moreover in our study; thrombocytopenia was found to be the only related parameter for longer hospital stay in cases with HAV infections. Although thrombocytopenia had been associated with longer hospital stay, we could not suggest any positive or negative correlation between thrombocytopenia and acute hepatic failure or transplantation, because in our study one patient had undergone transplantation on the first day of hospitalization due to hepatic encepholapathy and the other two had liver transplantation on the ninth and eleventh days due to the cholestatic hepatitis and fulminant hepatitis.

In our study coagulopathy was reported to be higher in comparison with previous studies and had been the most common reason for hospitalization. Previous reports from India indicated that coagulopathy had been observed in 12 cases $(15.4 \%)$ and abnormal APTT in 10 cases $(12.8 \%)^{(12)}$. The coagulation parameters had returned to normal levels within one-two days spontaneously or with $\mathrm{K}$ vitamin administration. Only the patients who had liver transplantation in the future had longer coagulation parameters despite multiple vitamin $\mathrm{K}$ administrations. However due to low number of liver transplanted patients, no further statistical analysis could be performed. Coagulation or requirement of $\mathrm{K}$ vitamin did not affect the duration of hospitalization excluding liver transplantation patients. In a previous study from Turkey ${ }^{(7)}$, positive correlation between PT and PTT levels and duration of hospitalization had been reported; however we had observed no difference in the incidence of coagulopathy during longer and shorter hospital stays.

The course of HAV infection can be atypical in $7 \%$ of the cses as in the forms of cholestatic, recurrent, or fulminant hepatitis (14). In a study from Turkey, atypical forms was reported as 1.4 percent $^{(7)}$. In a study from India, atypical forms was reported in $1.7 \%$ of the patients ${ }^{(12)}$. In our study, atypical cases were seen at a lower percent $(2.25 \%)$. of hospitalized patients.

In conclusion; thrombocytopenia at the presentation of HAV infections in children may be the predictor for longer hospital stay while age, ALT and AST levels, coagulopathy may not. It should be kept in mind that our findings mainly have focused on longer hospital stay not on acute liver failure; and each patient with HAV infection should be evaulated individiually for potential development of acute liver failure.

\section{REFERENCES}

1. Jacobsen KH, Koopman JS. Declining hepatitis A seroprevalence: A global review and analysis. Epidemiol Infect 2004;132:1005-22. https://doi.org/10.1017/S0950268804002857

2. Jacobsen KH, Koopman JS. The effects of socioeconomic development on worldwide hepatitis A virus seroprevalence patterns. Int J Epidemiol 2005;34:600-9. https://doi.org/10.1093/ije/dyi062

3. World Health Organization. Hepatitis A fact sheet No. 328. http://www.who.int/mediacentre/factsheets/fs328/en. Accessed 21 December 2014.

4. Koff RS. Hepatitis A. Lancet 1998;351:1643-9. https://doi.org/10.1016/S0140-6736(98)01304-X

5. Stapleton TJ, Lemon SM. Infectious diseases. In: Hoeprich PD, Jordan MC, Ronald AR, editors. Hepatitis A and Hepatitis E. $5^{\text {th }}$ edition. Philadelphia: Saunders. 1998; 790800 .

6. Sharapov UM. Hepatitis A. In: Yellow Book; 2010. Available online: http://wwwnc.cdc.gov/travel/yellowbook/2012/ chapter-3-infectious-diseases-related-to-travel/hepatitis-a. htm. Accessed 21 December 2014.

7. Çetinkaya B, Tezer H, Parlakay AÖ, Saylı TR. Evaluation of pediatric patients with hepatitis A. J Infect Dev Ctries 2008;8:326-30.

8. Kanra G, Tezcan S, Badur S. Hepatitis A seroprevalence in a random sample of the Turkish population by simultaneous EPI cluster and comparison with surveys in Turkey. Turk $J$ 
Pediatr 2002;44:204-10.

9. Ceyhan M, Yildirim I, Kurt N, et al. Differences in hepatitis A seroprevalence among geographical regions in Turkey: a need for regional vaccination recommendations. $J$ Viral Hepat 2008; 15:69-72. https://doi.org/10.1111/j.1365-2893.2008.01034.x

10. Moon HW, Cho JH, Hur M, et al. Laboratory characteristics of recent hepatitis A in Korea: ongoing epidemiological shift. World J Gastroenterol 2010;16(9):1115-8. https://doi.org/10.3748/wjg.v16.i9.1115

11. Arteaga A, Carrasco-Garrido P, de Andres AL, de Miguel AG, Jiménez-García R. Trends of hepatitis A hospitalizations and costs associated with the hospitalization in Spain (20002005). J Viral Hepat 2009;16:286-91. https://doi.org/10.1111/j.1365-2893.2009.01075.x

12. Kumar KJ, Kumar HC, Manjunath VG, Anitha C, Mamatha $\mathrm{S}$. Hepatitis A in children-clinical course, complications and laboratory profile. Indian J Pediatr 2014;81:15-9. https://doi.org/10.1007/s12098-013-1114-8

13. Victor JC, Surdina TY, Suleimenova SZ, Favorov MO, Bell BP, Monto AS. Person-to-person transmission of hepatitis A virus in an urban area of intermediate endemicity: implications for vaccination strategies. Am J Epidemiol 2006;163:204210.

https://doi.org/10.1093/aje/kwj029

14. Ciocca M. Clinical course and consequences of hepatitis A infection. Vaccine 2000;1:71-74.

https://doi.org/10.1016/S0264-410X(99)00470-3 